\title{
ANALISIS FAKTOR-FAKTOR YANG MEMPENGARUHI KINERJA ANGGOTA DITLANTAS KEPOLISIAN DAERAH NTT
}

\author{
John EHJ. FoEh ${ }^{1}$ \\ Universitas Bhayangkara Jakarta Raya \\ johnfoeh@gmail.com \\ Eliana Papote ${ }^{2}$ \\ Universitas Katolik Widya Mandira \\ papoteeliana1@gmail.com
}

Diterima 19 May 2021

Disetujui 19 June 2021

\begin{abstract}
The research objectives were to determine: 1) The description of performance, organizational culture, education and training, competence and work motivation of Indonesian National Police members at the Traffic Directorate of East Nusa Tenggara Regional Police; 2) The influence of organizational culture, education and training, competence and work motivation on the performance of Police members at the East Nusa Tenggara Regional Police Traffic Directorate. The study was conducted on all members of the East Nusa Tenggara Police Traffic Directorate with 145 respondents. The data collected were analyzed descriptively based on the results of processed data using the method of Structural Equation Model. The results of descriptive analysis showed that the achievement of the indicators for each variable is as follows: Performance $=67.68$ (Good Enough), Organizational Culture $=68.84($ Good $)$, Competence $=67.93($ Good Enough $)$, Education and Training $=67.45($ Good Enough), and Work Motivation = 68.55 (Good). Furthermore, the results of SEM analysis showed that Organizational Culture, Education and Training, Competence and Work Motivation had a positive and significant effect on the Performance of the investigated Police Members. This research is still limited to the 4 variables used so that testing is needed on other variables such as; leadership style, compensation, work atmosphere, work facilities and others with job satisfaction as an intervening variable.
\end{abstract}

Keywords: Performance; Organizational Culture; Education and Training; Competence; Work Motivation

\section{PENDAHULUAN}

Sesuai Peraturan Kapolri Nomor 14 Tahun 2018 tentang Susunan Organisasi dan Tata Kerja Kepolisian Daerah menyatakan bahwasanya Direktorat lalu lintas (Ditlantas) merupakan bagian penyelenggara yang tugas utamanya dalam bidang keamanan, keselamatan, ketertiban, dan kelancaran lalu lintas. Ditlantas berada pada tingkat Polda di bawah Kepala Kepolisian Daerah. Ditlantas Polda Nusa Tenggara Timur (NTT) menurut Budiman \& Riyanto (2013) memiliki tugas sebagai pelaksana dan melakukan pembinaan tehadap fungsi lalu lintas kepolisian, seperti menjaga, mengatur, mengawal dan berpatroli, memberikan pemahaman kepada masyarakat dan melakukan rekayasa lalu lintas, meregistrasi dan mengidentifikasi pengemudi bermotor, menyidik ketika ada kecelakaan lalu lintas, dan menegakkan hukum dalam bidang lalu lintas. Dalam menjalankan tugas dan fungsi sehari-sehari, Ditlantas Polda NTT dibantu oleh Satuan Kerja (Satker) yang meliputi: Subbagian Perencanaan dan Administrasi (Subbagrenmin), Bagian Pembinaan Operasional (Bagbinopsnal), Subdirektorat 
Pendidikan Masyarakat dan Rekayasa (Subditdikyasa), Subdirektorat Pembinaan Penegakan Hukum (Subditbingakkum), Subdirektorat Registrasi dan Identifikasi (Subditregident), Subdirektorat Keamanan dan Keselamatan (Subditkamsel), serta Satuan Patroli Jalan Raya (Sat PJR).

Asal mula kata 'kinerja' yakni dari kata job performance atau actual perfomance yang memiliki arti keberhasilan kerja atau keberhasilan seseorang yang telah tercapai dalam kerja. Menurut Nurlaila (2010) kinerja merupakan pencapaian yang diterima oleh seseorang, baik secara kualitas maupun kuantitas, ketika telah berhasil menyelesaikan pekerjaan sesuai dengan tugas pokok dan fungsi dengan penuh tanggung jawab. Byar dan Rue (dalam Edy, 2016) mengemukakan bahwa faktor-faktor yang mempengaruhi kinerja pegawai ada 2 yaitu faktor individu (usaha, kemampuan, perilaku dan aktivitas); serta faktor lingkungan (kondisi fisik, peralatan, waktu, material, pendidikan dan pelatihan, supervisi, dan desain organisasi). Selajutnya Afandi (2018) berpendapat bahwa faktor yang mempengaruhi kinerja pegawai ada 7 (tujuh), yaitu: kemampuan, motivasi kerja, kompetensi, fasilitas kerja, budaya organisasi, kepemimpinan dan disiplin kerja. Faktor lain yang juga menentukan kinerja adalah pendidikan dan pelatihan yang adalah salah satu fungsi manajemen sumber daya manusia untuk mengembangkan kemampuan kerja pegawai (Edison, 2016; Hasibuan \& Malayu, 2009). Pendidikan dan pelatihan menjadi bagian terpenting sebagai langkah melakukan peningkatak terhadap kinerja seseorang dan kinerja perusahaan. Sumber daya manusia perlu dikembangkan sebagai upaya memberikan bantuan kepada manusia untuk melaksanakan tanggung jawab yang lebih tinggi dalam perusahaan (Irham, 2017; Fauzi \& Johar, 2018).

Penelitian mengenai kinerja pegawai telah banyak dilakukan oleh beberapa peneliti sebelumnya, dengan hasil yang berbeda pula menurut tempat dan waktunya. Demikian pula menurut penilaian internal tentang kinerja Ditlantas Polda NTT masih berada di bawah beberapa Polda lainnya di Indonesia. Kinerja anggota pada Ditlantar Polda NTT dalam melaksanakan tugas pokok dan fungsi tampak belum optimal karena masih menunjukan sejumlah kelemahan. Dalam penelitian ini, akan difokuskan pada 4 faktor yaitu: budaya organisasi, pendidikan dan pelatihan, kompetensi, dan motivasi kerja (Robbins, Stephen, \& Timothy, 2008). Empat faktor ini dipilih karena hal-hal yang dikemukakan Robbin, et al (2008) seperti kepemimpinan bersifat top-down yang ditetapkan dari strata kepemimpinan di atasnya. Disiplin merupakn keharusan dan bukan hal yang dapat ditawar. Fasilitas kerja tentu saja berkaitan dengan anggaran negara untuk sarana pendukung dan bersifat rahasia. Demikian halnya dengan kompensasi yang punya aturan tersendiri serta disesuaikan dengan jabatan, masa kerja, dan berbagai ketentuan lainnya.

Untuk itu penelitian akan dilaksanakan untuk mengetahui dan menganalisis hal pertama yang berkaitan dengan gambaran kinerja, budaya organisasi, pendidikan dan pelatihan, kompetensi dan motivasi kerja anggota pada Ditlantas Polda NTT. Tujuan selanjutnya adalah melihat dan melakukan analisis yang berpengaruh pada masing-masing budaya organisasi, pendidikan dan latihan, kompetensi, dan motivasi kerja terhadap kinerja anggota pada Dirlantas Lalu Lintas Polda NTT. Yang berbeda dengan penelitian terdahulu adalah variabel Pendidikan dan Latihan dipisahkan menjadi variabel Pendidikan dan pelatihan secara terpisah. Berikutnya, variabel kompetensi belum pernah diteliti terhadap anggota Polri, khususnya dari Direktorat Lalu Lintas.

\section{Metode Penelitian}

Populasi dalam penelitian ini adalah seluruh anggota pada Ditlantas Polda NTT yang berjumlah 145 orang. Jumlah populasi penelitian ini berukuran cukup kecil namun telah memenuhi syarat untuk analisis SEM, sehingga digunakan sensus / sampling jenuh yaitu 
seluruh anggota populasinya diteliti. Jumlah sampel ini telah mencukupi untuk menggunakan analisis SEM, karena lebih dari 100 walaupun kurang dari 200 (Haryadi \& Julianita, 2015). Berikut, dalam Tabel 1 memuat operasionalisasi variabel dan indikator-indikator variable penelitian.

\subsection{Definisi Operasional Variabel}

Tabel 1. Operasionalisasi Variabel Penelitian

\begin{tabular}{|c|c|c|c|}
\hline Variabel & Definisi Operasional & Indikator & Skala \\
\hline $\begin{array}{c}\text { Budaya Organisasi } \\
\left(\mathrm{X}_{1}\right)\end{array}$ & $\begin{array}{l}\text { Pada hakikatnya, budaya organisasi } \\
\text { memiliki fungsi guna mengurus } \\
\text { pegawai supaya bisa menguasai hal } \\
\text { beberapa hal, yakni (1) menyikapi } \\
\text { profesinya, (2) melakukan adaptasi } \\
\text { terhadap teman kerja dan lingkung, } \\
\text { dan (3) melakukan tindakan reaktif } \\
\text { dengan peraturan yang telah dibuat } \\
\text { oleh pimpinan. Apabila ketiga hal } \\
\text { tersebut bisa dipenuhi pegawai, maka } \\
\text { bisa terbentuk: (1) aturan nilai, (2) } \\
\text { kebiasaan kerja (habits), dan (3) etos } \\
\text { kerja yang bisa diinternalisasikan } \\
\text { dalam keseharian di perusahaan. } \\
\text { (Hariandja \& Efendi, 2002). }\end{array}$ & $\begin{array}{l}\text { Inovasi dan pengambilan } \\
\text { resiko, Perhatian } \\
\text { terhadap detail, Orientasi } \\
\text { hasil, Ori-entasi orang } \\
\text { dan Orientasi Tim }\end{array}$ & Ordinal (Likert) \\
\hline Kompetensi $\left(\mathrm{X}_{2}\right)$ & $\begin{array}{l}\text { Kompetensi merupakan keseluruhan } \\
\text { yang dipunyai oleh seseorang, } \\
\text { meliputi pemahaman, keterampilan, } \\
\text { dan faktor internal seseorang agar bisa } \\
\text { melakukan pekerjaan sesuai dengan } \\
\text { pemahaman dan keterampilan yang } \\
\text { dikuasai. (Hutapea, Parulian, \& } \\
\text { Thoha, 2007; Lubis, Yusniar, } \\
\text { Hermanto, \& Edison, 2018). }\end{array}$ & $\begin{array}{l}\text { Pengetahuan Dasar Yang } \\
\text { Dimiliki, Kemampuan } \\
\text { Per-hatian Terhadap } \\
\text { Kualitas, Efisiensi Kerja, } \\
\text { Keahlian, } \\
\text { Profesionalisme, Penga- } \\
\text { laman. }\end{array}$ & Ordinal (Likert) \\
\hline $\begin{array}{c}\text { Pendidikan dan } \\
\text { Pelatihan }\left(\mathrm{X}_{3}\right)\end{array}$ & $\begin{array}{l}\text { Penddikan dan pelatihan menurut } \\
\text { Simanjuntak (2011) merupakan } \\
\text { penginvestasian sumber daya } \\
\text { manusia guna sebagai langkah } \\
\text { melakukan peningkatan kapablitas } \\
\text { dan keterampilan kerja, sehingga } \\
\text { pegawai bisa meningkatkan kinerja. } \\
\text { Program tersebut dibutuhkan sebagai } \\
\text { upaya melakukan pemenuhan atau } \\
\text { kompensasi terkait tingkat } \\
\text { pendidikan dan kualitas pendidikan } \\
\text { yang masih minim. }\end{array}$ & $\begin{array}{l}\text { Isi pelatihan, Metode } \\
\text { pelatihan, Sikap dan } \\
\text { Keterampilan Instruktur, } \\
\text { Waktu pelatihan. }\end{array}$ & Ordinal (Likert) \\
\hline
\end{tabular}




\begin{tabular}{|c|c|c|c|}
\hline Variabel & Definisi Operasional & Indikator & Skala \\
\hline Motivasi Kerja $\left(\mathrm{X}_{4}\right)$ & $\begin{array}{l}\text { Motivasi menurut (Munandar, 2001) } \\
\text { berkaitan dengan munculnya tedensi } \\
\text { sebagi upaya tercapainya tujuan. } \\
\text { Dilanjutkan oleh Samsudin (2010) } \\
\text { menyebutkan bahwasanya terdapat } \\
\text { korelasi yang erat terkait kebutuhan } \\
\text { motivasi, tindakan atau perilaku, } \\
\text { tujuan dan kepuasaan dengan } \\
\text { perubahan yang memunculkan } \\
\text { adanya dukungan motivasi. } \\
\text { Kemunculan motivasi tersebut } \\
\text { disebabkan oleh kebutuhan dan } \\
\text { tindakan yang terpusat agar mencapai } \\
\text { tujuan. Jika tujuan tersebut bisa } \\
\text { dicapai, maka kepuasan tersebut bisa } \\
\text { dipenuhi dan bisa mengarah agar } \\
\text { dilakukan pengulangan. }\end{array}$ & $\begin{array}{l}\text { Faktor Intrinsik: } \\
\text { Pencapai-an, Pengakuan, } \\
\text { Tanggung jawab. } \\
\text { Faktor Ekstrinsik: } \\
\text { Kondisi Kerja, Kualitas } \\
\text { Pengaman-an Teknis, } \\
\text { Kualitas Hubungan } \\
\text { Interpersonal. }\end{array}$ & Ordinal (Likert) \\
\hline Kinerja (Y) & $\begin{array}{l}\text { Berdasarkan beberapa pendapat para } \\
\text { ahli bisa ditarik simpulan bahwasanya } \\
\text { kinerja sumber daya manusia } \\
\text { merupakan pencapaian hasil kerja } \\
\text { (output), dilihat dari segi kualitas dan } \\
\text { kuantitas, oleh seseorang saat } \\
\text { melakukan kewajiban kerjanya dan } \\
\text { bisa bertanggung jawab atas } \\
\text { pekerjaan yang telah dibebankan. }\end{array}$ & 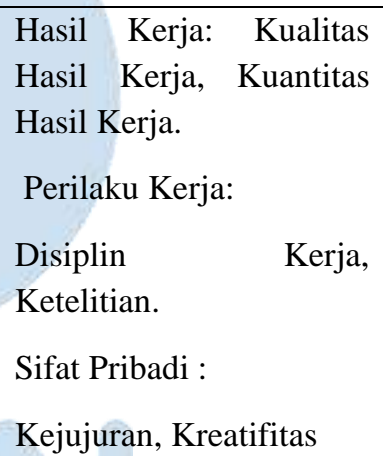 & Ordinal (Likert) \\
\hline
\end{tabular}

Jenis data yang digunakan dalam penelitian ini ada 2 yaitu data kualitatif berbentuk variable laten yang artinya variable-variabelnya tidak dapat diamati atau diukur secara langsung sehingga memerlukan beberapa indikator untuk mengukurnya (Suharsini, 2005). Selanjutnya, data kuantitatif, yaitu data yang diperoleh dari responden dalam bentuk angkaangka, yang kesemuanya dikumpulkan dengan menggunakan alat bantu kuesioner. Jawaban responden menggunakan skala Likert dengan 5 (lima) kategori pilihan jawaban, yakni: Sangat Tidak Setuju, Tidak Setuju, Cukup/Netral, Setuju dan Sangat Setuju.

Data hasil penelitian yang telah tertabulasi, selanjutnya dianalisis secara deskriptif dan analisis model persamaan structural (SEM) dengan langkah-langkah berikut. Analisis statistika deskriptif dilakukan dengan menghitung persepsi responden (Levis \& Rafael, 2013) dengan rumus:

$$
P s_{-p}=\left(\frac{\bar{X} P s_{-p}}{5}\right) \times 100 \%
$$

Keterangan :

$$
=\text { Kategori persepsi }
$$




$$
\begin{array}{ll}
P S_{-p} & \\
\bar{X} P s_{-p} & =\text { Rata-rata skor untuk persepsi populasi } \\
5 & =\text { Skor tertinggi skala Likert }
\end{array}
$$

Selanjutnya predikat atau kategori sikap dan rentang nilai uji deskriptif disajikan dalam Tabel 2 berikut:

Tabel 2. Predikat dan Rentang Nilai Uji Deskriptif

\begin{tabular}{|c|c|c|}
\hline No. & Pencapaian Skor Maksimum & Kategori Sikap/Predikat \\
\hline 1 & $84-100$ & Sangat Baik \\
\hline 2 & $68-83$ & Baik \\
\hline 3 & $52-67$ & Cukup Baik \\
\hline 4 & $36-51$ & Tidak Baik \\
\hline 5 & $\leq 20-35$ & Sangat Tidak Baik \\
\hline
\end{tabular}

Sumber: Levis \& Rafael (2013)

Analisis SEM dipergunakan dalam penelitian ini karena semua variabel yang dipergunakan bersifat laten yaitu untuk pengukurannya memerlukan beberapa indikator. Selanjutnya, indikator-indikator dimaksud dinilai dengan Skala Likert yang bersifat ordinal (Efferin, Darmadji, \& Y. Tjan, 2008). Sekalipun model penelitian tidaklah rumit sehingga bisa menggunakan analisis Regresi Linier Berganda namun model ini mensyaratkan penggunaan data dengan skala interval ataupun ratio. Selanjutnya, penelitian sosial umumnya menggunakan SEM yang dapat mengevaluasi kualitas pengukuran yaitu keandalan dan validitas alat ukur, khususnya korelasi sebab-akibat antar variabel yang tidak diamati atau variabel-variabel laten (Efferin et al., 2008)

Korelasi sebab-akibat antara variabel eksogen dengan variabel endogen dideskripsikan dengan mengoversi model kerangka pemikiran teoretis ke dalam diagram alur (path diagram). Gambar diagram alur tersebut dikonversi menggunakan SEM sehingga persamaan berubah estimasi. Terdapat faktor konstruk (construct) dalam SEM yang merupakan rancangan mendasar yang secara teoritis lebih bisa memberikan penjelasan dalam pelbagai macam korelasi alur sebab-akibat dari alur konstruk yang bisa digunakan berdasarkan variabel yang digunakan sebagai pengukur konstruk yang dibutuhkan. Penggambaran dalam membuat diagram alur yang menjadi tanda adanya korelasi konstruk yakni anak panah. Dalam SEM dikenal faktor (construct) yaitu konsep-konsep dengan dasar teoritis yang kuat untuk menjelaskan berbagai bentuk hubungan. Disini akan ditentukan alur sebab akibat dari konstruk yang akan dipakai dan atas dasar itu variabel-variabel untuk mengukur konstruk itu akan dicari. Penggambaran anak panah lurus menandakan korelasi sebab-akibatnya memiliki keterkaitan langsung antar konstruk. Penggambaran garis lengkung pada anak panah menandakan adanya keterkaitan antar konstruk. Konstruk pada diagram alur menurut Augusty (2014), dikelompokkan menjadi dua, yakni konstruk eksogen dan konstruk endogen. Konstruk eksogen disebut juga dengan source variables atau independent variables yang tidak bisa diduga oleh variabel lain. Konstruk eksogen merupakan konstruk yang dijadikan tujuan oleh garis dengan satu ujung panah. Konstruk endogen adalah faktor yang diperkirakan oleh satu atau beberapa konstruk. Konstruk endogen bisa memperkirakan adanya konstruk endogen lain, meskipun demikian, konstruk eksogen cuma bisa berkorelasi sebab-akibat dengan konstruk endogen. 


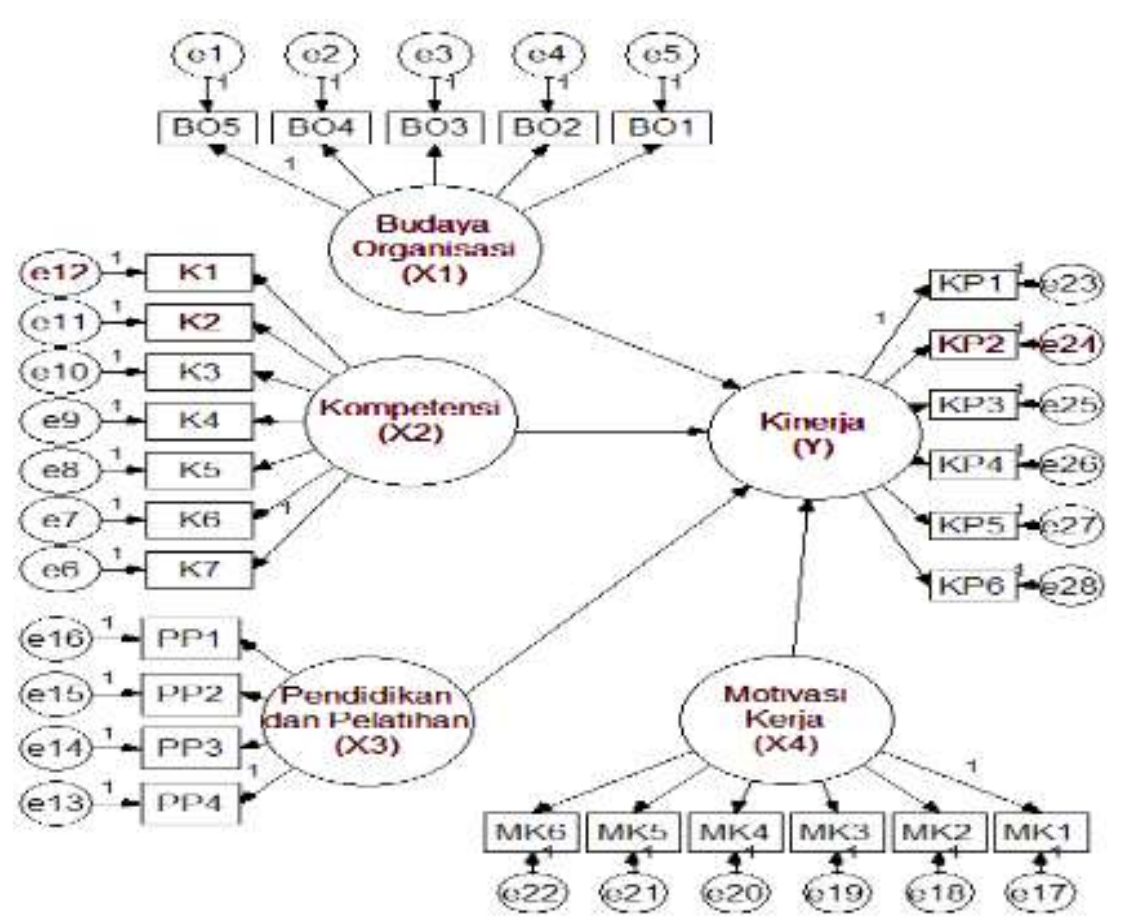

Gambar 1. Diagram Alur

Data yang digunakan, dievaluasi untuk dapat memenuhi asumsi-asumsi SEM sebagaimana diutarakan (Augusty, 2014), yaitu:

- Ukuran sampel. Ukuran sampel minimum yang disarankan dalam penggunaan SEM adalah sebanyak 100 .

- Normalitas dan linieritas. Data yang disebar dilakukan analisis guna mengetahui asumsi normalitas sudah terpenuhi. Normalitas bisa diuji dengan menggunakan gambar histogram data. Uji linieritas dilaksanakan dengan menggunakan scatterplots data, yakni dengan menentukan pasangan data dan mengetahui pola sebaran guna memprediksi kelinieritasan.

- Outliers. Outliers adalah mengamati adanya nilai-nilai ekstrim, baik secara univariat atau multivariat yang timbul adanya gabungan karateristik unik yang dipunyai dan bisa membedakan dari pengamatan yang lain.

- Multikolinearitas dan singularitas. Permasalahan multikolineritas dan singularitas dapat terindikasi dengan melihat nilai determinan matriks kovarians yang bernilai sangat kecil. Perlakuan yang diimplementasikan yakni melakukan eliminasi terhadap penyebab multikolinieritas dan singularitas.

- Terdapat jenis fit index yang bisa mengukur derajat kesesuaian antara model yang diduga dengan data yang dipaparkan, antara lain sebagai berikut (Augusty, 2014):

$\circ \mathrm{X}^{2}$ (Chi-square) statistic. Alat uji yang paling dasar guna menghitung overall fit merupakan likehood ratio Chi-square statistik. Chi-square memiliki sifat sangat sensitif terhadap besarnya sampel yang ujikan.

- GFI (Goodnes of Fit). Secara teoretis angka GFI berkisar antara 0 (poor fit) sampai 1 (perfect fit) dengan acuan bahwasanya semakin baik model tersebut dalam memaparkan data yang ada. Nilai GFI yang diharapkan sebesar $\geq 0,90$.

- AGFI (Adjusted Goodnes of Fit). AGFI adalah analog $\mathrm{R}^{2}$ dalam regresi berganda. Fit index bisa disesuaikan dengan degress offreedom yang tersedia guna melakukan 
pengujian penerimaan model. Tingkat penerimaan yang rekomendasikan adalah apabila AGFI mempunyai nilai $\geq 0,90$

- CMIN/DF (The Minimum Sample Discrepancy Function atau Degree of Freedom). CMIN/DF ialah nilai $C h i$ square dibagi dengan $D F$. Ukuran fit dalam nilai rasio $\leq$ 2,0 .

- TLI (Tucker Lewis Index) merupakan sebuah alternatif incremental fit index yang melakukan perbandingan model yang akan dilakukan pengujian dengan baseline mode. Saran nilai yang dijadikan pedoman penerimaan model yakni $\geq 0,95$.

- CFI (Comparative Fit Index). Pada hakikatnya, indeks angka NCP (Non Centrality Parameter) akan dibandingkan dengan pelbagai model. CFI yang berada dekat dengan 1 menjadi indikator tingkat fit tertinggi. Saran nilai CFI yakni $\geq 0,95$.

- RMSEA (The Root Mean Square Error of Approximation) merupakan indeks yang bisa dipakai guna memberikan keringanan pada Chi-square Statistic dengan sampel yang banyak. Nilai RMSEA $\leq 0,80$ ialah penerimaan model agar bisa membuktikan close fit berdasar pada kebebasan (degrees of freedom).

\subsection{Kerangka Pikir Penelitian}

Keberhasilan organisasi dalam mencapai tujuannya tidak terlepas dari adanya dukungan dari faktor-faktor yang mendukung keberhasilan tersebut. Faktor-faktor tersebut antara lain: budaya organisasi, kompetensi, motivasi kerja, dan kinerja anggota (Suharsini, 2005). Kuatnya budaya organisasi serta tingginya kompetensi dan motivasi kerja yang berdampak pada peningkatan kinerja anggota organisasi sehingga dapat dikatakan bahwa keempatnya saling mempunyai hubungan keterkaitan yang sangat erat dalam menentukan keberhasilan organisasi. Sesungguhnya kinerja organisasi dipengaruhi oleh beberapa faktor lainnya seperti kompensasi, disiplin kerja, gaya kepemimpinan, fasilitas kerja dan lain-lain, namun karena organisasi kepolisian bersifat komando dengan disiplin tinggi maka hal-hal tertentu tidak dapat ditelusuri karena menyangkut bersifat sensitive. Berdasar pada beberapa uraian tersebut, maka bisa digambarkan kerangka pemikiran sebagaimana tercantum dalam Gambar 2, termasuk kaitannya dengan hipotesis-hipotesis yang dirumuskan berikutnya.

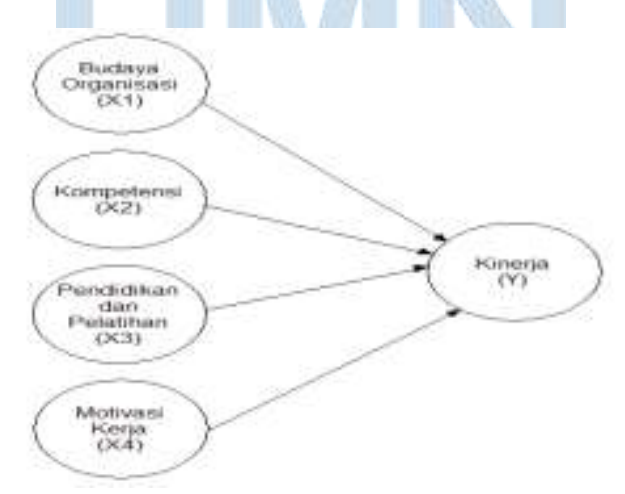

Gambar 2. Kerangka Pikir Penelitian

\subsection{Hipotesis}

Berdasarkan kerangka pemikiran tersebut, dapat diajukan hipotesis sebagai berikut:

- Budaya organisasi berpengaruh positif dan signifikan terhadap kinerja anggota Ditlantas Polda NTT. 
- Kompetensi berpengaruh positif dan signifikan terhadap kinerja anggota Ditlantas Polda NTT.

- Pendidikan dan Pelatihan berpengaruh positif dan signifikan terhadap kinerja anggota Ditlantas Polda NTT

- Motivasi kerja berpengaruh positif dan signifikan terhadap kinerja anggota Ditlantas Polda NTT

\section{HASIL PENELITIAN DAN DISKUSI 3.1 Analisis Deskriptif}

Rata-rata angka persepsi responden untuk variabel kinerja adalah sebesar 67,68 dan jika dibandingkan dengan predikat rentang nilai uji deskriptif dikatakan bahwa capaian ini berada dalam rentang 52-67 dengan predikat cukup baik. Rata-rata angka persepsi responden untuk variabel budaya organisasi sebesar 68,94 dan jika dibandingkan dengan predikat rentang nilai uji deskriptif dikatakan bahwa capaian ini berada dalam rentang 68-83 dengan predikat baik. Rata-rata angka persepsi responden untuk variabel kompetensi adalah sebesar 67,93. Dari 7 (tujuh) indikator yang diteliti, 2 (dua) indikator memperoleh predikat baik dan 5 (lima) indikator lainnya memperoleh predikat cukup baik. Dengan capaian rata-rata ini, dapat dikatakan bahwa capaian ini berada dalam rentang 52-67 dengan predikat cukup baik. Ratarata angka persepsi responden untuk variabel pendidikan dan pelatihan sebesar 67,45 dan jika dibandingkan dengan predikat rentang nilai uji deskriptif dikatakan bahwa capaian ini berada dalam rentang 52-67 dengan predikat cukup baik. Variabel motivasi kerja berada dalam rentang predikat baik, dengan rata-rata angka persepsi responden sebesar 68,55. Capaian indikator terendah adalah indikator pencapaian yaitu sebesar 68,07 dan capaian tertinggi adalah pada indikator tanggung jawab yaitu sebesar 69,17.

Dari hasil penelitian ini nampak bahwa 2 variabel yaitu budaya organisasi dan motivasi kerja berkategori baik yang tidak terlepas dari pola organisasi Polri yang bersifat komando dengan disiplin yang tinggi. Selanjutnya nilai rata-rata dari kompetensi, Pendidikan dan Latihan dinilai hanya cukup baik karena dengan system anggaran dan personalia yang terbatas maka berakibat pada kesempatan untuk bisa meningkatkan kompetensi melalui Diklat yang dilaksanakan Polri. Hal ini juga berakibat pada kinerja anggota yang masih masuk kategori cukup baik. Namun demikian hasil ini perlu dibandingkan dengan standar kinerja rata-rata institusi, termasuk perbandingan dengan wilayah Polda lainnya di Indonesia.

\subsection{Analisis Statistik Inferensial}

\subsubsection{Uji Validitas dan Reliabilitas}

Hasil uji validitas yang dilakukan sebelumnya menunjukkan bahwa seluruh item pernyataan untuk variabel kinerja, budaya organisasi, kompetensi, pendidikan dan pelatihan serta motivasi kerja mempunyai nilai koefisien korelasi jauh lebih besar dari 0,3 sehingga dinyatakan valid. Untuk itu seluruh pernyataan yang diajukan dalam kuesioner penelitian ini dapat digunakan untuk mengukur variabel-variabel penelitian dimaksud. Selanjutnya, hasil uji reliabilitas menunjukkan bahwa seluruh item pernyataan memiliki nilai koefisien alpha Cronbach lebih besar dari 0,6 sebagaimana yang disyaratkan, sehingga semua item pernyataan dinyatakan reliabel dan dapat digunakan untuk mengukur variabel-variabel penelitian. 


\subsubsection{Analisis Faktor Konfirmatori (Confirmatory Factor Analysis)}

Analisis faktor konfirmatori adalah tahap penghitungan terhadap dimensi-dimensi yang membentuk variabel laten dalam model penelitian (Farouk \& Djaali, 2010). Berdasarkan hasil kalkulasi data terlihat bahwa semua indikator -dari seluruh variabel yang diteliti- sudah terpenuhi dan dapat dikatakan fit. Selain itu untuk menguji undimensionalitas indikatorindikator dari masing-masing variabel, dapat dilakukan dengan melihat bagian "estimates". Hasil analisis CFA untuk seluruh variabel (kinerja, budaya organisasi, kompetensi, Pendidikan dan Latihan serta motivasi kerja) menandakan korelasi yang baik, yaitu nilai CR untuk semua indikator di atas, 1.96 atau dengan probabilitas sebesar 0,000 atau lebih kecil dari 0,05. Hasil tersebut bisa menunjukkan bahwasanya terdapat indikator pembentuk semua variabel yang menandakan undimensionalitas. Berdasarkan analisis faktor konfirmatori konstruk ini, maka model penelitian dapat digunakan untuk analisis selanjutnya.

\subsubsection{Analisis Structural Equition Modelling (SEM)}

Analisis selanjutnya adalah analisis SEM secara full model, setelah dilakukan analisis terhadap tingkat undimensionalitas dari indikator pembentuk variabel laten yang diuji dengan analisis faktor konfirmatori. Analisis hasil pengolahan data pada tahap full model SEM dilakukan dengan menguji kesuaian dan uji statistik. Hasil pengolahan data untuk analisis full model SEM terdapat dalam Gambar 3 sebagai berikut:

\section{STRUCUTRAL EQUATION MODEL}

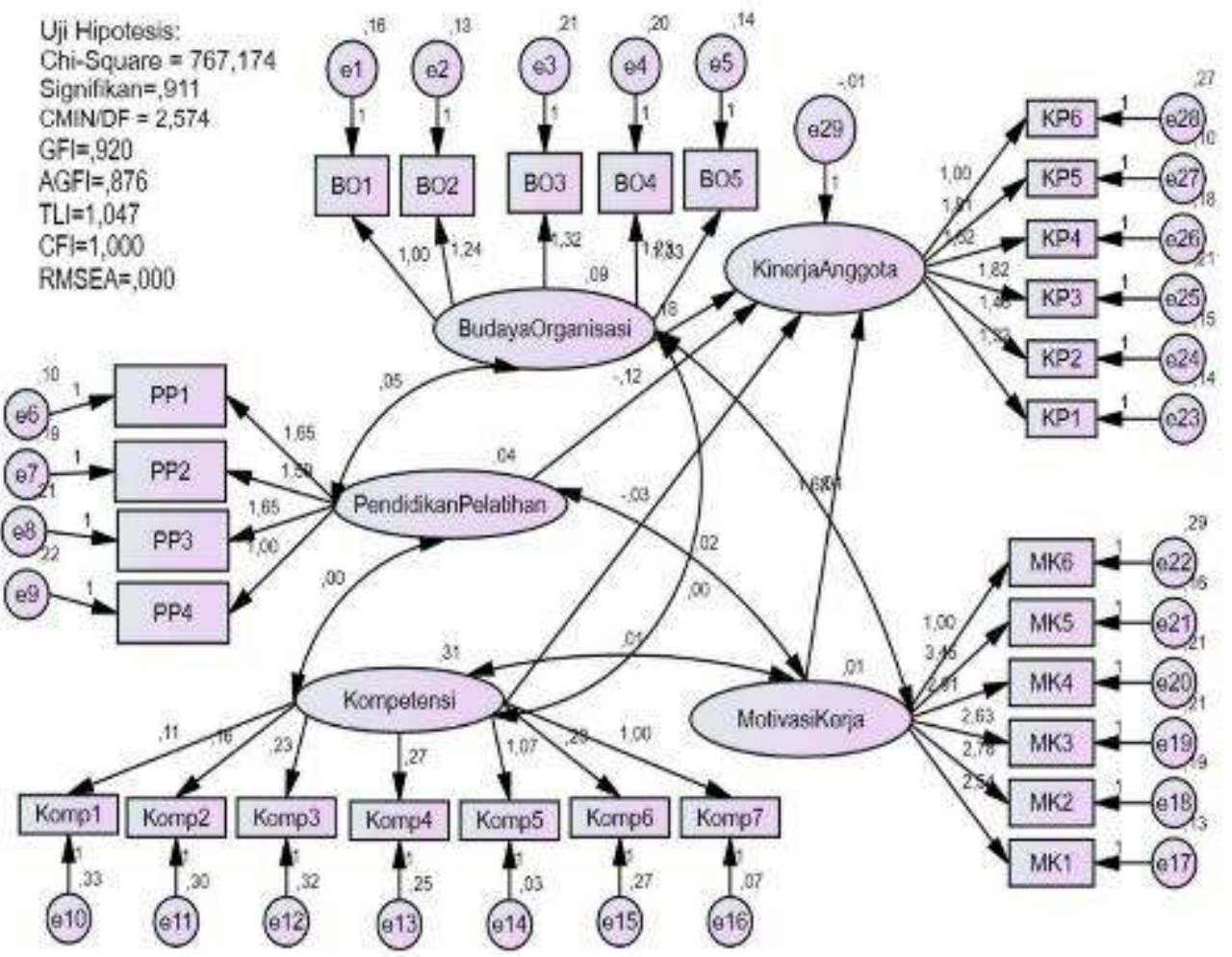

Gambar 3. Hasil Uji SEM

Uji terhadap kelayakan full model SEM diuji dengan menggunakan Chi square, GFI, CFI, TLI, CMIN/DF, dan RMSEA berada dalam rentang nilai yang menunjukkan semua nilai dari 
indikator telah memenuhi syarat atau kategori Good Fit, kecuali, meskipun nilai AGFI masih marginal tetapi mendekati 1 (satu) sehingga dapat diterima.

\subsubsection{Pengujian asumsi SEM}

\section{- Nilai Outliers}

Outlier adalah observasi atau data yang memiliki karakteristik unik yang terlihat sangat berbeda dengan data lainnya dan muncul dalam bentuk nilai ekstrim, baik untuk variabel tunggal maupun kombinasi. Asumsi SEM selanjutnya adalah outlier, asumsinya adalah terdapat outlier jika nilai mahalonobis d-squared > Chi-Square. Asumsi SEM selanjutnya adalah terdapat nilai outlier jika nilai mahalonobis d-squared $>$ Chi-Square. Berdasarkan hasil olahan data (Lampiran 6), dapat disimpulkan bahwa semua nilai mahalonobis d-squared < chi-squared (767.174) sehingga disimpulkan bahwa tidak terdapat multivariate outliers.

\section{- Normalitas Data}

Pengujian selanjutnya adalah melihat tingkat normalitas data yang digunakan dalam penelitian ini. Pengujian ini adalah dengan mengamati nilai skewness data yang digunakan, apabila nilai CR pada skewness data berada pada rentang antara \pm 2.58 ($2.58<\mathrm{CR}<2.58$ ) atau berada pada tingkat signifikan 0.01. Uji normalitas secara univariate dapat dilakukan dengan melihat nilai CR dari skew dan kurtosis, dimana nilai kedua ratio yang memiliki nilai yang lebih besar dari nilai mutlak 2.58 , berarti data tersebut berdistribusi normal. Dari data di atas, diketahui bahwa tidak terdapat nilai CR untuk skewness yang berada diluar rentang \pm 2.58 . Dengan demikian maka data penelitian yang digunakan telah memenuhi persyaratan normalitas data, atau dapat dikatakan bahwa data penelitian telah terdistribusi normal.

- Asumsi atas Multicollinearity dan Singularity

Pengujian selanjutnya adalah melihat apakah terdapat multikolinearitas dan singularitas dalam sebuah kombinasi variabel. Indikasi adanya multikolinearitas dan singularitas dapat diketahui melalui nilai determinan matriks kovarians yang benar-benar kecil, atau mendekati nol. Dari hasil pengolahan data dapat dilihat nilai determinan matriks kovarians sampel adalah determinant of sample covariance matrix $=0.000$.

- Evaluasi Nilai Residual

- Setelah model di estimasi residualnya haruslah kecil atau mendekati nol dan distribusi frekuensi dari kovarian residual harus bersifat simetrik. Jika suatu model memiliki nilai kovarians residual yang tinggi, maka sebuah modifikasi perlu dipertimbangkan dengan catatan landasan teoritisnya. Bila ditemukan bahwa nilai residual yang dihasilkan oleh model itu cukup besar $(\geq 2.58)$, maka cara lain dalam memodifikasi adalah dengan mempertimbangkan untuk menambah sebuah alur baru terhadap model yang di estimasi. Data standarized residual covariances yang diolah dengan program AMOS memberikan hasil bahwa nilai residual tidak lebih besar dari 2.58, sehingga dapat dikatakan bahwa residual mendekati pola dan distribusi frekuensi dari kovarian yang bersifat simetrik. 


\subsection{Pengujian Hipotesis}

Setelah semua asumsi terpenuhi, selanjutnya akan dilakukan pengujian hipotesis sebagaimana diajukan pada bab sebelumnya. Pengujian 4 hipotesis penelitian ini dilakukan berdasarkan nilai Critical Ratio (CR) suatu hubungan kausalitas dari hasil pengolahan data SEM seperti tertera dalam Tabel 3.

Tabel 3. Pembobotan Regresi pada Analisis SEM

\begin{tabular}{|l|r|l|r|r|r|r|r|r|}
\hline & & Estimate & S.E. & C.R. & p & Label & $\begin{array}{l}\text { Standarized } \\
\text { Regression } \\
\text { Weight }\end{array}$ \\
\hline $\begin{array}{l}\text { Kinerja } \\
\text { Anggota }\end{array}$ & $<-$ & Kompetensi &, 259 &, 073 & 3,551 & 444 & par_24 &, 275 \\
\hline $\begin{array}{l}\text { Kinerja } \\
\text { Anggota }\end{array}$ & $<-$ & $\begin{array}{l}\text { Eudaya } \\
\text { Organiaga }\end{array}$ &, 603 &, 147 & 4,105 & 444 & par_25 &, 845 \\
\hline $\begin{array}{l}\text { Kinerja } \\
\text { Anggota }\end{array}$ & $<-$ & $\begin{array}{l}\text { Pendidikan } \\
\text { Pelatihan }\end{array}$ & 1,933 &, 647 & 2,987 &, 003 & par_26 &, 505 \\
\hline $\begin{array}{l}\text { Kinerja } \\
\text { Anggota }\end{array}$ & $<-$ & $\begin{array}{l}\text { Motivasi } \\
\text { Kerja }\end{array}$ & 4,005 & $\begin{array}{r}1,99 \\
2\end{array}$ & 2,010 &, 044 & par_27 &, 700 \\
\hline
\end{tabular}

Sumber: Hasil Olah Data, 2020

Berdasarkan hasil analisis SEM pada Tabel 3. maka dilakukan pengujian-pengujian hipotesis sebagai berikut:

- Pengujian Hipotesis 1

Berdasarkan hasil pembobotan regresi SEM, nilai koefisien regresi sebesar 0,845, dengan nilai probabilitas sebesar 0,000 atau < 0.05 (Noor, 2014). Sehingga dapat dikatakan bahwa Budaya Organisasi berpengaruh positif dan signifikan terhadap Kinerja Anggota. Dengan demikian, maka hipotesis pertama diterima.

- Pengujian Hipotesis 2

Berdasarkan hasil pembobotan regresi SEM, nilai koefisien regresi sebesar 0,275, dengan nilai probabilitas sebesar 0,000 atau $<0.05$. Sehingga dapat dikatakan bahwa kompetensi berpengaruh positif dan signifikan terhadap Kinerja Anggota. Dengan demikian, maka hipotesis kedua diterima.

- Pengujian Hipotesis 3

Berdasarkan hasil pembobotan regresi SEM, nilai koefisien regresi sebesar 0,505, dengan nilai probabilitas sebesar 0,003 atau $<0.05$. Sehingga dapat dikatakan bahwa pendidikan dan pelatihan berpengaruh positif dan signifikan terhadap Kinerja Anggota. Dengan demikian, maka hipotesis ketiga diterima.

- Pengujian Hipotesis 4

Berdasarkan hasil pembobotan regresi SEM, nilai koefisien regresi sebesar 0,400, dengan nilai probabilitas sebesar 0,044 atau $<0.05$. Sehingga dapat dikatakan bahwa motivasi kerja berpengaruh positif dan signifikan terhadap Kinerja Anggota. Dengan demikian, maka hipotesis keempat diterima. 


\subsection{Pembahasan}

\subsubsection{Pengaruh Budaya Organisasi Terhadap Kinerja Anggota pada Ditlantas Polda NTT}

Hasil pembobotan regresi SEM, menunjukkan bahwa nilai koefisien regresi variabel budaya organisasi terhadap kinerja adalah sebesar 0,845 dengan nilai probabilitas sebesar 0,000 atau < 0.05. Sehingga bisa dinyatakan bahwasanya Budaya Organisasi berpengaruh positif dan signifikan terhadap Kinerja Anggota (Robbins \& Stephen, 2002). Hasil ini sekaligus menerima hipotesis pertama. Dengan demikian, jika budaya organisasi ditingkatkan atau diperbaiki maka kinerja anggota Ditlantas Polda NTT juga akan meningkat.

Hasil dari penelitian ini sejalan dengan penelitian yang dilakukan oleh Suprijono (2015) dengan judul "Pengaruh Budaya Organisasi dan Motivasi Terhadap Kinerja Karyawan (perawat) Pada Rumah Sakit Wijaya Kusuma Kabupaten Lumajang" yang memperoleh hasil budaya organisasi berpengaruh signifikan terhadap kinerja Karyawan (perawat) Rumah Sakit Wijaya Kusuma Kabupaten Lumajang. Hasil penelitian ini juga sejalan dengan pendapat Armstrong (dalam Sudarmanto, 2009) mengungkapakan bahwasanya budaya organisasi sebagai bagian penting dalam mencapai misi dan strategi organisai yang memiliki keefektifan dan manajemen perubahan. Lingkungan kerja yang nyaman dan aman guna sebagai upaya memperbaiki kinerja dan manajemen perubahan (Rachmawati, 2008; Rivai., 2011)

\subsubsection{Pengaruh Kompetensi Terhadap Kinerja Anggota pada Ditlantas Polda NTT}

Hasil pembobotan regresi SEM, menunjukkan bahwa nilai koefisien regresi sebesar 0,275 dengan nilai probabilitas sebesar 0,000 atau $<0.05$. Untuk itu dapat dikatakan bahwa kompetensi berpengaruh positif dan signifikan terhadap Kinerja Anggota. Hasil ini sekaligus menerima hipotesis kedua. Dengan demikian, jika kompetensi anggota ditingkatkan maka kinerja anggota Ditlantas Polda NTT juga akan meningkat. Hasil dari penelitian ini sejalan dengan penelitian yang dilakukan oleh Adiputra (2014) dengan judul "Pengaruh Pendidikan Pelatihan dan Kompetensi Terhadap Kinerja Anggota Satuaan Reskrim Pada Polres Kota Metro Lampung" yang memperoleh hasil bahwa kompetensi berpengaruh signifikan dalam mempengaruhi kinerja personil Polisi bagian reserse kriminal di kantor Polisi Resor Kota Metro Lampung. Hasil penelitian ini juga sejalan dengan pendapat Spencer (dalam Moeheriono, 2009), yang mengemukakan bahwa hubungan antara kompetensi karyawan dengna kinerja adalah sangat erat dan penting sekali, relevansinya ada dan kuat, bahkan karyawan apabila ingin meningkatkan kinerja, seharusnya memiliki kompetensi yang sesuai dengan tugas pekerjaannya (Palan, 2007). Oleh karena itu pengelolaan sumber daya manusia memang harus dikelola secara benar dan seksama agar tujuan dan sasaran organisasi dapat dicapai melalui pengelolaan sumber daya manusia yang optimal.

\subsubsection{Pengaruh Pendidikan dan Pelatihan Terhadap Kinerja Anggota Ditlantas Polda NTT}

Dengan cara pembobotan regresi SEM yang sama, menunjukkan bahwa nilai koefisien regresi sebesar 0,505 dengan nilai probabilitas sebesar 0,003 atau $<0.05$ sehingga dapat dikatakan bahwa pendidikan dan pelatihan berpengaruh positif dan signifikan terhadap Kinerja Anggota. Hasil ini sekaligus menerima hipotesis ketiga. Dengan demikian, jika pendidikan dan pelatihan yang diberikan pada anggota ditingkatkan, maka kinerja anggota Ditlantas Polda NTT juga akan meningkat. Hasil dari penelitian ini sejalan dengan penelitian yang dilakukan oleh Adiputra (2014) dengan judul "Pengaruh Pendidikan Pelatihan dan Kompetensi Terhadap Kinerja Anggota Satuaan Reskrim Pada Polres Kota Metro Lampung" yang memperoleh hasil bahwa pendidikan dan pelatihan berpengaruh signifikan dalam mempengaruhi kinerja personil 
Polisi bagian reserse kriminal di kantor Polisi Resor Kota Metro Lampung. Hasil penelitian ini juga sejalan dengan pendapat Pandi Afandi (2018) mengemukakan bahwa pendidikan dan pelatihan adalah salah satu fungsi manajemen sumber daya manusia untuk mengembangkan kemampuan kerja pegawai. Pendidikan dan pelatihan menjadi salah satu komponen yang sangat penting dalam meningkatkan kinerja pegawai dan kinerja organisasi. Pengembangan sumber daya manusia membantu mereka untuk memikul tanggung jawab yang lebih tinggi dalam organisasi (Sedarmayanti, 2007; Sastrohadiwiryo, 2002).

\subsubsection{Pengaruh Motivasi Kerja Terhadap Kinerja Anggota Ditlantas Polda NTT}

Melalui mekanisme pembobotan regresi SEM, menunjukkan bahwa nilai koefisien regresi sebesar 0,400 dengan nilai probabilitas sebesar 0,044 atau $<0.05$, sehingga dapat dikatakan bahwa motivasi kerja berpengaruh positif dan signifikan terhadap Kinerja Anggota. Hasil ini sekaligus menerima hipotesis ke empat. Dengan demikian, jika motivasi kerja anggota semakin baik, maka kinerja anggota Ditlantas Polda NTT juga akan meningkat. Hasil dari penelitian ini sejalan dengan penelitian yang dilakukan oleh Syafitri Diah (2014) dengan judul "Pengaruh Budaya Organisasi dan Motivasi Kerja Terhadap Kinerja Pegawai di Kantor Regional I Badan Kepegawaian Negara Yogyakarta" yang memperoleh hasil bahwa terdapat pengaruh positif dan signifikan dari motivasi kerja terhadap kinerja pegawai Kantor Regional I Badan Kepegawaian Negara Yogyakarta. Hasil penelitian ini juga sejalan dengan pendapat Mangkunegara \& Prabu (2008) bahwa terdapat hubungan antara motivasi kerja terhadap kinerja. Faktor yang mempengaruhi kinerja di antaranya adalah motivasi kerja (Manzoor, 2012). Hal ini dilihat dari pernyataan Simamora (1997) mengenai faktor-faktor yang mempengaruhi kinerja, di antaranya faktor psikologis dimana dalam faktor ini terdapat variabel motivasi kerja terhadap pekerjaannya sendiri. Berdasarkan dari pernyataan dimaksud di atas, dapat dikatakan bahwa terdapat hubungan antara motivasi kerja dengan kinerja.

\section{KESIMPULAN, IMPLIKASI DAN KETERBATASAN PENELITIAN}

\subsection{Kesimpulan}

- Hasil analisis statistik deskriptif menunjukkan variabel kinerja, kompetensi, pendidikan dan pelatihan berada dalam kategori cukup baik. Variabel budaya organisasi dan motivasi kerja berada dalam kategori baik. Dengan demikian, kinerja, kompetensi, pendidikan dan pelatihan masih perlu ditingkatkan.

- $\quad$ Budaya organisasi berpengaruh positif dan signifikan terhadap kinerja Anggota pada Ditlantas Polda NTT.

- Kompetensi berpengaruh positif dan signifikan terhadap kinerja Anggota pada Ditlantas Polda NTT.

- Pendidikan dan Pelatihan berpengaruh positif dan signifikan terhadap kinerja Anggota pada Ditlantas Polda NTT.

- Variabel motivasi kerja berpengaruh positif dan signifikan terhadap kinerja Anggota pada Ditlantas Polda NTT. 


\subsection{Implikasi Penelitian}

- Polda NTT, khususnyaDirektorat Lalu Lintas perlu melakukan perbaikanperbaikan terhadap SDM yang ada untuk dapat meningkatkan kinerja anggotanya melalui pengembangan kompetensi serta program pendidikan dan latihan agar menuju ke kategori baik. Untuk itu, diperlukan analisis perbandingan dengan SDM pada direktorat lainnya di Polda NTT maupun dibandingkan dengan Poldapolda lainnya di Indonesia.

- Secara umum ditemukan bahwa seluruh variable (budaya organisasi, kompetensi, Diklat dan motivasi kerja) berpengaruh positih dan signifikan terhadap kinerja anggota Ditlantas Polda NTT, namun tetap perlu diperbandingkan dengan standar kinerja sesuai peraturan Kapolri dan diperbandingkan dengan kinerja Ditlantas di kota-kota besar lainnya di Indonesia.

- Disarankan agar anggota Ditlantas Polda NTT mempertahankan predikat baik pada budaya organisasi dan motivasi kerja. Selanjutnya, meningkatkan kinerja, kompetensi serta pendidikan dan pelatihan. Salah satu cara adalah dengan memberi penekanan kepada tiap anggota bahwa untuk menjadi anggota Kepolisian Republik Indonesia yang professional dan berkinerja sekurangkurangnya baik, maka anggota dituntut untuk lebih giat dalam berbagai hal sesuai dengan Standar Operasional Prosedur (SOP) yang berlaku.

- Jajaran Ditlantas Polda NTT seyogianya terus memperbaiki dan meningkatkan kompetensi, serta pendidikan dan pelatihan bagi para anggotanya. Hal ini dapat dilakukan dengan cara: mengikutsertakan anggota dalam kegiatan sertifikasi kompetensi lalu lintas; menyediakan anggaran agar lebih sering memberikan pelatihan bagi anggota serta jumlah anggota yang ikut pelatihan dapat ditingkatkan; dan melakukan kegiatan yang dapat membina kebersamaan dan kekeluargaan antar anggota.

\subsection{Keterbatasan Penelitian}

- Pengukuran kinerja karyawan termasuk anggota Ditlantas Polda NTT merupakan hal yang komplek. Kinerja tidak hanya dipengaruhi oleh budaya organisasi, kompetensi, diklat dan motivasi kerja, akan tetapi masih banyak faktor lain yang tidak digunakan dalam penelitian ini yang dapat mempengaruhi tinggi atau rendahnya kinerja anggota.

- Penelitian hanya terbatas pada budaya organisasi, kompetensi, diklat dan motivasi kerja tidak menjelaskan mengenai pengaruh setiap dimensi pada kinerja anggota Ditlantas Polda NTT. Tambahan, diperlukan tambahan pengujian terhadap variabel-variabel lain seperti, gaya kepemimpinan, kompensasi, suasana kerja, fasilitas kerja dan lain-lain dengan kepuasan kerja sebagai variabel intervening. Variabel-variabel ini belum diteliti di sini karena menyangkut hal yang cukup sensitive dan memerlukan persetujuan institusi.

- Penelitian ini menggunakan metode survey melalui kuesioner yang dikirimkan ke seluruh anggota Ditlantas Polda NTT yang jumlah populasinya hanya 145 orang. Dengan demikian jika penelitian ini diterapkan ke jumlah populasi atau sampel 
yang lebih besar maka pasti variasinya hasil yang akan diperoleh pasti lebih bisa menggambarkan kondisi yang sesungguhnya.

\section{REFERENSI}

Adiputra, R. F. (2014). Pengaruh Pendidikan Pelatihan Dan Kompetensi Terhadap Kinerja Anggota Satuaan Reskrim Pada Polres Kota Metro Lampung. 1-13.

Afandi, P. (2018). Manajemen Sumber Daya Manusia, Teori, Konsep dan Indikator. Riau:

Zanafa Publishing.

Augusty, F. (2014). Metode Penelitian Manajemen. Semarang: Universitas Diponegoro.

Budiman, \& Riyanto. (2013). PERANAN SATLANTAS POLRESTA SURAKARTA DALAM MENANGANI MASALAH KECELAKAAN LALU LINTAS DI KOTA SURAKARTA.

Edison, E. (2016). Manajemen Sumber Daya Manusia. Bandung: Alfabet.

Edy, S. (2016). Manajemen Sumber Daya Manusia. Jakarta: Kencana Prenada Media Group.

Efferin, S. S. ., Darmadji, \& Y. Tjan. (2008). Metode Penelitian Akuntansi; Mengungkap Fenomena dengan Pendekatan Kualitatif dan Kuantitatif. (Edisi Pert). Yogyakarta: Graha Ilmu.

Farouk, M., \& Djaali. (2010). Metodologi Penelitian Sosial. Jakarta: Restu Agung.

Fauzi, A., \& Johar, A. (2018). Aplikasi Excel dalam Aspek Kuantitatif Manajemen Sumber Daya Manusia. Jakarta: PT Elex Media Komputindo.

Ghozali, I. (2011). Aplikasi Analisis Multivariate dengan Program IBM SPSS 19. Universitas Diponegoro.

Hariandja, \& Efendi, M. T. (2002). Manajemen Sumber Daya Manusia. Jakarta: Grasindo.

Haryadi, S., \& Julianita, W. (2015). Structural Equation Modeling (SEM); Sebuah Pengantar Aplikasi untuk Penelitian Bisnis. Jakarta: Salemba Empat.

Hasibuan, \& Malayu, S. (2009). Manajemen Sumber Daya Manusia (Revisi). Jakarta: Bumi Aksara.

Hutapea, Parulian, \& Thoha, N. (2007). Kompetensi Plus. Jakarta: Gramedia Pustaka Utama.

Irham, F. (2017). Reformasi Birokrasi Publik di Indonesia, Teori dan Aplikasi. Bandung: Alfabeta.

Levis, \& Rafael, L. (2013). Metode Penelitian Perilaku Petani. Maumere: Ledalero.

Lubis, Yusniar, Hermanto, B., \& Edison, E. (2018). Manajemen dan Riset Sumber Daya Manusia. Bandung: Alfabeta.

Mangkunegara, \& Prabu, A. (2008). Manajemen Sumber Daya Manusia Perusahaan. Bandung: Remaja Rosdakarya.

Manzoor, M. (2012). The Importance of Higher Education Websites and its Usability. International Journal of Basic and Applied Sciences, 1(2), 150-163.

Moeheriono. (2009). Pengukuran Kinerja Berbasis Kompetensi. Bogor: Ghalia.

Munandar, A. . (2001). Psikologi Industri dan Organisasi. Jakarta: Universitas Indonesia.

Noor, J. (2014). Analisis Data Penelitian Ekonomi dan Manajemen. Jakarta: Grasindo.

Nurlaila. (2010). Manajemen Sumber Daya Manusia. Yogyakarta: Pustaka Pelajar. 
Palan, R. (2007). Competency Management: Teknis Mengimplementasikan Manajemen SDM Berbasis Kompetensi Untuk Meningkatkan Daya Saing Organisasi. Jakarta: PPM.

Rachmawati, K. (2008). Manajemen Sumber Daya Manusia. Yogyakarta: ANDI.

Rivai., V. (2011). Manajemen Sumber Daya Manusia untuk Perusahaan: dari Teori ke Praktik. Jakarta: Raja Grafindo Persada.

Robbins, \& Stephen, P. (2002). Prinsip-Prinsip Perilaku Organisasi. Jakarta: Erlangga.

Robbins, STephen, P., \& Timothy, A. (2008). Perilaku Organisasi. Jakarta: Salemba Empat.

Samsudin, S. (2010). Manajemen Sumber Daya Manusia. Bandung: Pustaka Setia.

Sastrohadiwiryo, S. (2002). Manajemen Tenaga Kerja Indonesia Pendekatan Administrasi dan Operasional. Jakarta: Bumi Aksara.

Sedarmayanti. (2007). Manajemen Sumber Daya Manusia, Reformasi Birokrasi, Dan Manajemen.

Simamora, H. 1997. Manajemen Sumber Daya Manusia. Yogyakarta : Bagian Penerbitan STIE.

Simanjuntak, P. (2003). Manajemen hubungan industrial. Jakarta: Pustaka Sinar Harapan.

Sudarmanto. (2009). Kinerja dan Pengembangan Kompetensi SDM. Yogyakarta: pustaka belajar.

Suharsini, A. (2005). Manajemen Penelitian. Jakarta: Rineka Cipta.

Suprijono, A. (2015). Cooperative Learning. Yogyakarta: pustaka belajar.

Syafitri Diah, K. (2014). Pengaruh Budaya Organisasi dan Motivasi Kerja Terhadap Kinerja Pegawai Di Kantor Regional I Badan Kepegawaian Negara Yogyakarta. Applied Microbiology and Biotechnology, 85(1), 2071-2079. 